\title{
Competency evaluation for careers in business intelligence analysis
}

\author{
Mark Fox, Indiana University South Bend,mfox1@iusb.edu \\ Jennifer L. Breese, Penn State University, jzb545@psu.edu \\ Ganesh Vaidyanathan, Roosevelt University,gvaidyanathan@roosevelt.edu
}

\begin{abstract}
We use the US Occupational Resource Network (O*NET) to derive competencies required of those pursuing careers as Business Intelligence Analysts (BIA). Specifically, we look at the knowledge, skills, abilities, and work styles required of BIA occupations. We then group those competencies into more meaningful, but related, competency categories that we call: personal effectiveness competencies; communication competencies; cognitive competencies; management \& interpersonal skills; systems competencies; and mathematics, statistics, and applications. We contrast the competencies we found with those mentioned in previous studies and conclude by making some observations about the implications of our research.
\end{abstract}

Keywords: business data, business intelligence analyst, business data analyst, competencies, careers

\section{Introduction}

The Bureau of Labor Statistics categorizes occupations by Standard Occupational Classifications (SOCs). The SOC that most closely correlates to big data analytics is 15-2050 Data Scientists. That occupational category is defined as involving those who:

"Develop and implement a set of techniques or analytics applications to transform raw data into meaningful information using data-oriented programming languages and visualization software. Apply data mining, data modeling, natural language processing, and machine learning to extract and analyze information from large structured and unstructured datasets. Visualize, interpret, and report data findings. May create dynamic data reports." (National Center for O*NET Development, 2021a)

The SOC Data Scientists category incorporates two subcategories, namely Business Intelligence Analysts (15-2051.01) and Clinical Data Managers (15-2051.02). Our focus is on Business Intelligence Analysts. Business Intelligence Analysts (BIA) include jobs with titles such as: Business Intelligence Analyst, Competitive Intelligence Analyst, Data Analyst, Intelligence Analyst, Market Intelligence Analyst, Market Intelligence Consultant, Strategic Business and Technology Intelligence Consultant, Strategist (National Center for O*NET Development, 2021b). In 2019, the Bureau of Labor Statistics estimated there were 33,200 jobs for data scientists and mathematical science occupations (including BIA jobs), and from 2019 to 2029 an additional 10,300 new jobs in these areas were predicted (a growth of $31 \%$, which is much faster than average) (Bureau of Labor Statistics, 2021). 


\section{Issues in Information Systems}

Volume 22, Issue 4, pp. 157-167, 2021

We use O*NET in this study as other researchers have used it in the past (e.g., Burrus et al., 2013; Cifuentes et al., 2010; Hadden et al., 2004; Zimmerman et al., 2004). O*NET is particularly useful as it creates standardized occupation-specific descriptors and it is based on surveys of job incumbents.

The purpose of our research is to identify the most important competencies needed by Business Intelligence Analysts so as to help educators with curriculum design in this fast-changing field. Our research is also useful for students and human resource professionals, who may be evaluating the relevance of different programs to their needs. In the next section we identify the competencies needed by business intelligence analysts. We then compare those competencies with those competencies that have been identified by other researchers. The final section includes the conclusion and the implications of our research.

\section{Competency areas for business intelligence analyst jobs}

O*NET provides importance rankings that "indicates the degree of importance a particular descriptor is to the occupation" (National Center for O*NET Development, 2021c). We look at these importance rankings for each of competencies areas that are the focus of this paper (namely knowledge, skills, abilities, and work styles). Importance rankings are provided by $\mathrm{O}^{*} \mathrm{NET}$ on a scale of 0 to 100 , where zero is not important and 100 is the highest possible score. O*NET defaults to listing rankings that have numerical scores of at least 50 and we do the same (50 is the mid-range for something to be considered "important"). We now turn our attention to the each of the competency areas for BIA jobs, namely, knowledge, skills, abilities and work styles. These four areas form the basis for the competencies needed for BIA jobs. We focus on these areas as they were deemed to be important by Burrus et al. (2013), who focused on those areas after examining previous research. From O*NET we identified the following items with importance scores of 50 or higher:

- Four knowledge competencies, each of which comprises "Organized sets of principles and facts applying in general domains" (National Center for O*NET Development, 2021d);

- Sixteen skill areas, where skills are "Developed capacities that facilitate learning or the more rapid acquisition of knowledge" (National Center for O*NET Development, 2021d);

- Seventeen ability areas, where abilities are "Enduring attributes of the individual that influence performance" (National Center for O*NET Development, 2021d); and

- Fifteen work style areas, i.e., "Personal characteristics that can affect how well someone performs a job" (National Center for O*NET Development, 2021d). As with abilities, these can be developed through education and experience.

Specifically, we generated knowledge, skill, ability, and work style competencies using the custom report feature in O*NET (National Center for O*NET Development, 2021a). The knowledge areas with importance rankings over 50 (out of 100) appear in Table 1, and the skills, abilities and work styles with ratings over 50 (out of 100) are in Tables 2 and 3. Most of the abilities required are cognitive abilities and a few are sensory abilities. 


\section{Issues in Information Systems}

Volume 22, Issue 4, pp. 157-167, 2021

Table 1: Knowledge Requirements for Business Intelligence Analysts

\begin{tabular}{|l|l|c|}
\hline Knowledge & Knowledge description & Importance \\
\hline English Language & $\begin{array}{l}\text { Knowledge of the structure and content of the English language } \\
\text { including the meaning and spelling of words, rules of } \\
\text { composition, and grammar. }\end{array}$ & 76 \\
\hline Mathematics & $\begin{array}{l}\text { Knowledge of arithmetic, algebra, geometry, calculus, statistics, } \\
\text { and their applications. }\end{array}$ & 58 \\
\hline $\begin{array}{l}\text { Administration } \\
\text { and Management }\end{array}$ & $\begin{array}{l}\text { Knowledge of business and management principles involved in } \\
\text { strategic planning, resource allocation, human resources } \\
\text { modeling, leadership technique, production methods, and } \\
\text { coordination of people and resources. }\end{array}$ & 51 \\
\hline $\begin{array}{l}\text { Computers and } \\
\text { Electronics }\end{array}$ & $\begin{array}{l}\text { Knowledge of circuit boards, processors, chips, electronic } \\
\text { equipment, and computer hardware and software, including } \\
\text { applications and programming. }\end{array}$ & 51 \\
\hline
\end{tabular}

Table 2: Skills and Abilities for Business Intelligence Analysts

\begin{tabular}{|c|c|c|c|}
\hline Skills & Importance & Abilities & Importance \\
\hline $\begin{array}{l}\text { Reading Comprehension: } \\
\text { Understanding written sentences and } \\
\text { paragraphs in work related documents. }\end{array}$ & 75 & $\begin{array}{l}\text { Written Comprehension: The } \\
\text { ability to read and understand } \\
\text { information and ideas presented in } \\
\text { writing. }\end{array}$ & 78 \\
\hline $\begin{array}{l}\text { Critical Thinking: Using logic and } \\
\text { reasoning to identify the strengths and } \\
\text { weaknesses of alternative solutions, } \\
\text { conclusions or approaches to problems. }\end{array}$ & 75 & $\begin{array}{l}\text { Written Expression: The ability } \\
\text { to communicate information and } \\
\text { ideas in writing so others will } \\
\text { understand. }\end{array}$ & 78 \\
\hline $\begin{array}{l}\text { Active Listening: Giving full attention } \\
\text { to what other people are saying, taking } \\
\text { time to understand the points being } \\
\text { made, asking questions as appropriate, } \\
\text { and not interrupting at inappropriate } \\
\text { times. }\end{array}$ & 72 & $\begin{array}{l}\text { Oral Comprehension: The } \\
\text { ability to listen to and understand } \\
\text { information and ideas presented } \\
\text { through spoken words and } \\
\text { sentences. }\end{array}$ & 75 \\
\hline $\begin{array}{l}\text { Speaking: Talking to others to convey } \\
\text { information effectively. }\end{array}$ & 72 & $\begin{array}{l}\text { Oral Expression: The ability to } \\
\text { communicate information and } \\
\text { ideas in speaking so others will } \\
\text { understand. }\end{array}$ & 75 \\
\hline $\begin{array}{l}\text { Writing: Communicating effectively in } \\
\text { writing as appropriate for the needs of } \\
\text { the audience. }\end{array}$ & 69 & $\begin{array}{l}\text { Inductive Reasoning: The ability } \\
\text { to combine pieces of information } \\
\text { to form general rules or } \\
\text { conclusions (includes finding a } \\
\text { relationship among seemingly } \\
\text { unrelated events). }\end{array}$ & 75 \\
\hline $\begin{array}{l}\text { Active Learning: Understanding the } \\
\text { implications of new information for } \\
\text { both current and future problem-solving } \\
\text { and decision-making. }\end{array}$ & 69 & $\begin{array}{l}\text { Deductive Reasoning: The ability } \\
\text { to apply general rules to specific } \\
\text { problems to produce answers that } \\
\text { make sense. }\end{array}$ & 72 \\
\hline
\end{tabular}




\title{
Issues in Information Systems
}

\author{
Volume 22, Issue 4, pp. 157-167, 2021
}

\begin{tabular}{|c|c|c|c|}
\hline $\begin{array}{l}\text { Judgment and Decision Making: } \\
\text { Considering the relative costs and } \\
\text { benefits of potential actions to choose } \\
\text { the most appropriate one. }\end{array}$ & 66 & $\begin{array}{l}\text { Category Flexibility: The ability } \\
\text { to generate or use different sets of } \\
\text { rules for combining or grouping } \\
\text { things in different ways. }\end{array}$ & 69 \\
\hline Skills & Importance & Abilities & Importance \\
\hline $\begin{array}{l}\text { Complex Problem Solving: Identifying } \\
\text { complex problems and reviewing } \\
\text { related information to develop and } \\
\text { evaluate options and implement } \\
\text { solutions. }\end{array}$ & 63 & $\begin{array}{l}\text { Information Ordering: The } \\
\text { ability to arrange things or actions } \\
\text { in a certain order or pattern } \\
\text { according to a specific rule or set } \\
\text { of rules (e.g., patterns of numbers, } \\
\text { letters, words, pictures, } \\
\text { mathematical operations). }\end{array}$ & 66 \\
\hline $\begin{array}{l}\text { Mathematics: Using mathematics to } \\
\text { solve problems. }\end{array}$ & 60 & $\begin{array}{l}\text { Speech Clarity: The ability to } \\
\text { speak clearly so others can } \\
\text { understand you. }\end{array}$ & 66 \\
\hline $\begin{array}{l}\text { Systems Analysis: Determining how a } \\
\text { system should work and how changes in } \\
\text { conditions, operations, and the } \\
\text { environment will affect outcomes. }\end{array}$ & 60 & $\begin{array}{l}\text { Speech Recognition: The ability } \\
\text { to identify and understand the } \\
\text { speech of another person. }\end{array}$ & 63 \\
\hline $\begin{array}{l}\text { Systems Evaluation: Identifying } \\
\text { measures or indicators of system } \\
\text { performance and the actions needed to } \\
\text { improve or correct performance, } \\
\text { relative to the goals of the system. }\end{array}$ & 56 & $\begin{array}{l}\text { Fluency of Ideas: The ability to } \\
\text { come up with a number of ideas } \\
\text { about a topic (the number of ideas } \\
\text { is important, not their quality, } \\
\text { correctness, or creativity). }\end{array}$ & 60 \\
\hline $\begin{array}{l}\text { Time Management: Managing one's } \\
\text { own time and the time of others. }\end{array}$ & 56 & $\begin{array}{l}\text { Problem Sensitivity: The ability } \\
\text { to tell when something is wrong or } \\
\text { is likely to go wrong. It does not } \\
\text { involve solving the problem, only } \\
\text { recognizing there is a problem. }\end{array}$ & 60 \\
\hline $\begin{array}{l}\text { Monitoring: Monitoring/Assessing } \\
\text { performance of yourself, other } \\
\text { individuals, or organizations to make } \\
\text { improvements or take corrective action. }\end{array}$ & 53 & $\begin{array}{l}\text { Mathematical Reasoning: The } \\
\text { ability to choose the right } \\
\text { mathematical methods or formulas } \\
\text { to solve a problem. }\end{array}$ & 60 \\
\hline $\begin{array}{l}\text { Learning Strategies: Selecting and } \\
\text { using training/instructional methods and } \\
\text { procedures appropriate for the situation } \\
\text { when learning or teaching new things. }\end{array}$ & 50 & $\begin{array}{l}\text { Flexibility of Closure: The ability } \\
\text { to identify or detect a known } \\
\text { pattern (a figure, object, word, or } \\
\text { sound) that is hidden in other } \\
\text { distracting material. }\end{array}$ & 56 \\
\hline $\begin{array}{l}\text { Coordination: Adjusting actions in } \\
\text { relation to others' actions. }\end{array}$ & 50 & $\begin{array}{l}\text { Originality: The ability to come } \\
\text { up with unusual or clever ideas } \\
\text { about a given topic or situation, or } \\
\text { to develop creative ways to solve } \\
\text { a problem. }\end{array}$ & 53 \\
\hline \multirow[t]{2}{*}{$\begin{array}{l}\text { Persuasion: Persuading others to } \\
\text { change their minds or behavior. }\end{array}$} & 50 & $\begin{array}{l}\text { Number Facility: The ability to } \\
\text { add, subtract, multiply, or divide } \\
\text { quickly and correctly. }\end{array}$ & 53 \\
\hline & & $\begin{array}{l}\text { Near Vision: The ability to see } \\
\text { details at close range (within a few } \\
\text { feet of the observer). }\end{array}$ & 53 \\
\hline
\end{tabular}




\section{Issues in Information Systems}

Volume 22, Issue 4, pp. 157-167, 2021

Table 3: Work Styles for Business Intelligence Analysts

\begin{tabular}{|l|c|}
\hline Work style & Importance \\
\hline $\begin{array}{l}\text { Analytical Thinking: Job requires analyzing information and using logic to } \\
\text { address work-related issues and problems. }\end{array}$ & 95 \\
\hline $\begin{array}{l}\text { Attention to Detail: Job requires being careful about detail and thorough in } \\
\text { completing work tasks. }\end{array}$ & 93 \\
\hline $\begin{array}{l}\text { Dependability: Job requires being reliable, responsible, and dependable, and } \\
\text { fulfilling obligations. }\end{array}$ & 85 \\
\hline Initiative: Job requires a willingness to take on responsibilities and challenges. & 82 \\
\hline Integrity: Job requires being honest and ethical. & 82 \\
\hline Persistence: Job requires persistence in the face of obstacles. & 81 \\
\hline $\begin{array}{l}\text { Cooperation: Job requires being pleasant with others on the job and displaying } \\
\text { a good-natured, cooperative attitude. }\end{array}$ & 76 \\
\hline $\begin{array}{l}\text { Achievement/Effort: Job requires establishing and maintaining personally } \\
\text { challenging achievement goals and exerting effort toward mastering tasks. }\end{array}$ & 74 \\
\hline $\begin{array}{l}\text { Adaptability/Flexibility: Job requires being open to change (positive or } \\
\text { negative) and to considerable variety in the workplace. }\end{array}$ & 74 \\
\hline $\begin{array}{l}\text { Independence: Job requires developing one's own ways of doing things, } \\
\text { guiding oneself with little or no supervision, and depending on oneself to get } \\
\text { things done. }\end{array}$ & 73 \\
\hline $\begin{array}{l}\text { Stress Tolerance: Job requires accepting criticism and dealing calmly and } \\
\text { effectively with high stress situations. }\end{array}$ & 63 \\
\hline $\begin{array}{l}\text { Innovation: Job requires creativity and alternative thinking to develop new } \\
\text { ideas for and answers to work-related problems. }\end{array}$ & 62 \\
\hline $\begin{array}{l}\text { Leadership: Job requires a willingness to lead, take charge, and offer opinions } \\
\text { and direction. }\end{array}$ & 58 \\
\hline $\begin{array}{l}\text { Self Control: Job requires maintaining composure, keeping emotions in check, } \\
\text { controlling anger, and avoiding aggressive behavior, even in very difficult } \\
\text { situations. }\end{array}$ & 54 \\
\hline $\begin{array}{l}\text { Concern for Others: Job requires being sensitive to others' needs and feelings } \\
\text { and being understanding and helpful on the job. }\end{array}$ & 51 \\
\hline
\end{tabular}

General listings of competencies such as those in Tables 1 through 3 have some value, but they are not as useful as grouping related competencies together into more meaningful, and related, categories. We did just this. In creating these overall competency categories we attempted to reach a balance between relevance and focus. Where there were multiple related items we tended to group these together, but not to bundle them into categories that were too small. Each of the three authors independently categorized the general competencies from Tables 1 to 3 into overall competency categories that we believe would be more helpful for teachers, practitioners, and students. The area where we had some difference of opinion was where to place persuasion skills, namely whether or not this constitutes a communication competency or is a management and interpersonal skills competency. We ultimately decided to limit the communication competencies to more basic communication skills (reading, speaking, writing). We also believed that, although persuasion is a communication skill, it is a more advanced skill that belongs more to the management and interpersonal skills competency category - which is ultimately where we placed it. 


\section{Issues in Information Systems}

Volume 22, Issue 4, pp. 157-167, 2021

Below, we present the overall competencies that we developed, i.e., the most important competency areas of BIA professionals. We order these from what can be seen as more foundational to more complex competencies, i.e., as we progress, the competencies (generally speaking) build upon one another. (As an aside, the only item that did not fit was a physical competency, namely "near vision"). The definitions for these competencies already appeared in Tables 1 to 3, above.

Personal effectiveness competencies are competencies that drive individuals to be engaged and motivated in the BIA field. These can be viewed as foundational competencies. Without these competencies individuals are unlikely to be motivated and able to succeed in the BIA field. The specific competencies that are related to personal effectiveness are as follows:

- Achievement/effort, attention to detail, dependability, independence, initiative, integrity, persistence, self-control, and stress tolerance.

Communication competencies involve being able to communicate effectively. These competencies are useful for BIA professionals as the job involves understanding the needs of others and then, once complex data is analyzed, communicating findings to others within their organizations (White, 2019).

- English language knowledge.

- Reading comprehension, speaking, active listening, and writing.

- Written comprehension and expression; oral comprehension and expression; speech clarity and recognition.

Cognitive competencies involve how we think about and solve problems. These competencies are needed as BIA professionals need to "distinguish relevant from irrelevant data, draw the right assumptions, and translate information into insights" (Sato \& Huang, 2015, p. 210). The cognitive competencies that we grouped into this category are as follows:

- Active learning, critical thinking, judgment and decision-making, and complex problem solving.

- Category flexibility, deductive and inductive reasoning, fluency of ideas, flexibility of closure, information ordering, originality, and problem sensitivity.

- Analytical thinking, adaptability/flexibility, and innovation.

Management and interpersonal skills: We grouped these competencies together as interpersonal skills are essential to effective management and management also involves the management of non-human resources, such as time.

- Knowledge of administration and management.

- Monitoring, coordination, learning strategies, persuasion, and time management.

- Cooperation, leadership, and concern for others.

Systems competencies: We grouped systems analysis and evaluation together as a distinct competency category as this is a distinct domain with information systems (although it may also involve the use of applications such as ERP systems; see, for example, Irani \& Love, 2001). Understanding systems is important for BIA professionals as one of their key roles is to make use of data in ways that create business value. That potential value can often be identified by evaluating current systems needs in light of emerging customer and competitor trends (White, 2019).

Statistics, mathematics and applications: We viewed this as the most complex of the competency groups as it involves not only statistical expertise, but also the ability to use various software tools. As one expert notes, "Through use of data analytics, data visualization and data modeling techniques and technologies, BI [Business Intelligence] analysts can identify trends that can help other departments, managers and 


\section{Issues in Information Systems}

Volume 22, Issue 4, pp. 157-167, 2021

executives make business decisions to modernize and improve processes in the organization" (White, 2019). The specific competencies that we grouped into this area are:

- Knowledge of computers and electronics

- Knowledge and skills in mathematics;

- Mathematical reasoning and number facility.

With regard to software applications, O*NET provides examples of technology skills for BIA jobs (see Table 4). What is striking about these is the wide range of software expertise required and the large number of these technologies that are categorized by $\mathrm{O}^{*} \mathrm{NET}$ as being "hot", i.e., that are mentioned frequently in job postings. O*NET identifies the "hot" technology skills by using a fire icon.

Table 4: Examples of Technology Skills for Business Intelligence Analysts

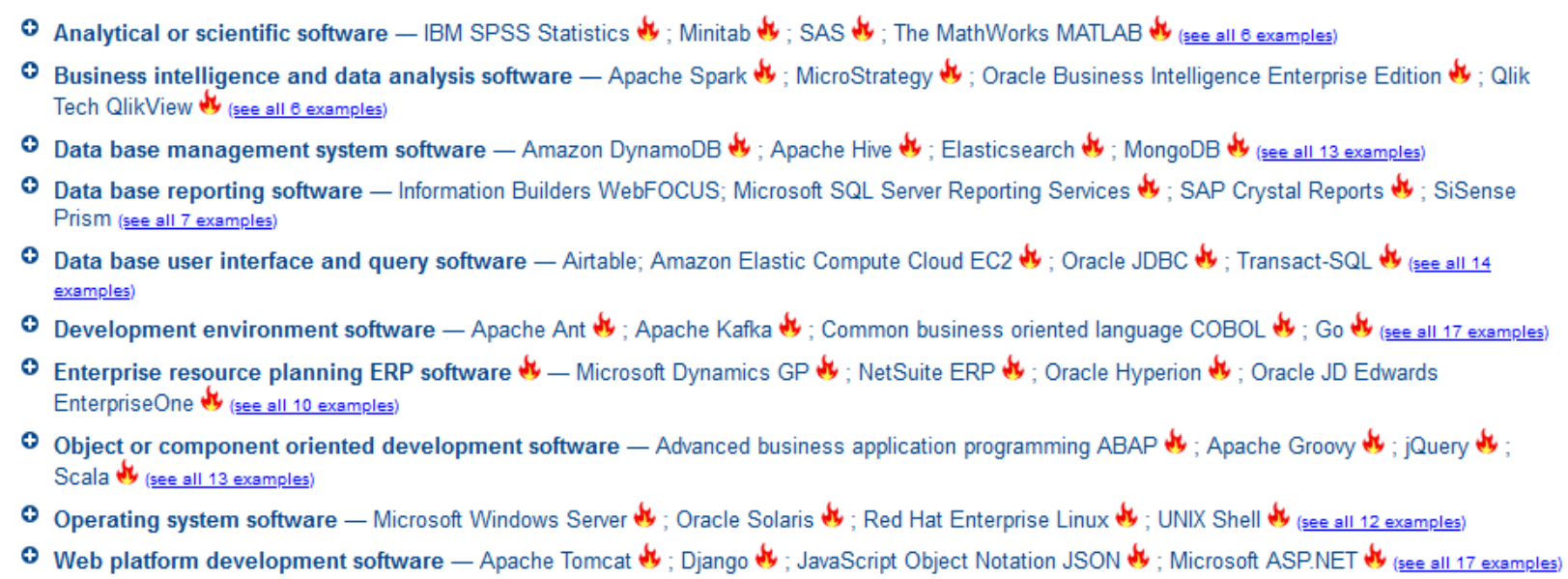

Source: Screenshot from National Center for O*NET Development (2021b). We used the default settings for 10 technologies, with up to four examples being given per category. Interested readers could vary these settings.

When discussing data scientists in general, Mikalef et al. (2018) noted that, "there is limited research on the discrepancies between the skills that are needed in the market and what graduates possess" (p. 1). Their finding is still largely true today. This is particularly true when we consider our area of interest, namely the subset of data scientists that are business intelligence analysts. Next, we look at key research previously undertaken in this area and contrast it with our own findings.

\section{Comparing our $\mathrm{O} * \mathrm{NET}$ findings with other studies}

A study by Debortoli et al. (2014) used text mining on job advertisements to compare BIA skills found that BIA skills could largely be categorizes as either business skills or IT skills. Descriptive terms such as "developer," "SQL server," "data warehouse," "ETL (extraction, transformation, and Loading)," and "BI developer" and associated titles of job ads such as "BI Developer SQL Server," "ETL Developer," and "SQL Server DBA" were assigned for BIA jobs. Terms like "sales," "business development," "marketing," "account," and "new business" described a second group of jobs with associated job titles such as "Business Development Manager BI," "Sales Executive BI," and "New Business Sales Executive." The first few highloading extracted factors were found to be job titles that include "Business Analyst" and "Business Development Manager". Of the job titles 6\% included titles such as "Business Analyst," "Business Analyst SAP APO Excel Expert," "Data Analyst," "Reporting Data Analyst," "BI Report Analyst," and "Technical Business Analyst". The factor loadings reported specific domains such as healthcare and digital marketing, specific managerial competencies such as project management, and specific IT competencies related to 


\section{Issues in Information Systems}

Volume 22, Issue 4, pp. 157-167, 2021

vendor-specific products (e.g., Microsoft, SAP, SAS) and those related to general concepts and methods (e.g., database administration, BI architecture) as the most dominating demands. SAP BusinessObjects, SAP Business Warehouse, SAP High Performance Analytical Appliance (HANA), SAS BI Platform, IBM BI Platform were found to be leading factors of technology competencies (Debortoli et al., 2014). The findings support the technology skillsets we found in O*NET.

De Mauro et al., (2018) also examined online job postings. For business analyst roles they found that database management, project management, systems management, analytics and business impact skills were the most mentioned in job postings. This is pretty much consistent with our findings, although the project management skills would have been somewhat subsumed into our management and interpersonal competencies category and the analytics and business impact skills would largely be within our statistics, mathematics and applications category.

Dubey and Gunasekaran (2015) interviewed the heads of business analytics for ten companies based in India. Based on these interviews and an examination of previous research the authors developed a framework of BDBA (Big Data and Business Analytics) that comprised hard skills (Statisticsisep, Forecasting, is Peptimization, sicpi:Multiple criteria decision making, Marketing, Research methods, Finance) and soft skills (Leadership ability, Team skills, Listening skills, Learning, Positive attitude, Communication skills, Interpersonal skills, Patience, Passion). What is interesting here is the prominence of finance skills among the hard skills and the inclusion of skills such as leadership ability, learning, passion and patience among the soft skills. This may be accounted for by the senior positions of those being interviewed.

Persaud (2020) examined job postings, programs BDA (business data analytics) programs offered by colleges and universities, and interviews with executives whose firms utilize BDA. The author developed a concept map of themes and data based on big data jobs. These themes were: data, computer science, information, source; business; customers; skills, and people. Also, text mining analysis yielded four broad categories of knowledge, skills, and abilities that employers are seeking for big data professions, namely: data analytics, computing, business, and soft skills. This is in line with the competencies presented in O*NET.

Business skills used to analyze and make decisions based on the analytical reports are important to both business analysts and data scientists. The most important and desirable skills for an entry role for a BIA include data analytics, modeling, and business strategy in the hard skills category; analytical, problem solving and written communication in the soft skills category; and SQL, Python and Java in the software skills category (Ozturk \& Hartzel, 2020).

In general, we see significant overlaps between the competencies we generated from O*NET for BIA jobs. Where there are differences this is likely a function of focus: we focused specifically on BIA jobs and on the framework used by O*NET, whereas many earlier studies were broader (focusing on big data or data analytics, rather than BIA specifically) or narrower (focusing just on, say, job advertisements).

\section{Implications and conclusions}

Business Intelligence Analysis has been predicted as an area that would lead to numerous jobs (Chen et al., 2012). There is clearly a need for individuals with knowledge in descriptive, predictive, and prescriptive analytics and in making good decisions using such analysis. Business intelligence analysis is usually covered in academic disciplines such as Information Systems, Computer Science, Statistics, and Business. Each discipline offers a niche in educating and graduating students to become BIA. 


\section{Issues in Information Systems}

Volume 22, Issue 4, pp. 157-167, 2021

Information systems programs offered in business schools and can provide a unique set of skills and knowledge to their students. To obtain such knowledge and skills, students must gather a holistic knowledge emphasizing in data management, business-oriented statistical analysis, management science techniques, and obtaining general business domain knowledge such as marketing, accounting, finance, and economics. Courses need to offer content focusing on data mining, text mining, opinion mining, social media/network analytics, web mining, and predictive analytics. The education for a BIA demands an interdisciplinary business and domain knowledge with a focus on statistical analysis of both structured data and unstructured text (Chen et al., 2012). Clayton and Clopton (2018) further elaborate that a team consisting of multidisciplinary faculty, advisory board members, and key alumni who work with data analytics must be involved to develop a BIA curriculum. Dubey and Gunasekaran (2015) recommended training as a complementary aspect for offering skills and knowledge to students. They argued a need to revamp the education system by analyzing a proper fit between education and training in order to improve the effectiveness of student learning outcomes.

The purpose of our research was to determine the most important competencies needed by Business Intelligence Analysts. The $\mathrm{O}^{*} \mathrm{NET}$ database was useful to transform mountains of data from job incumbents into precise, focused occupational intelligence that can be understood easily and efficiently by educators, employers, and students alike. Our findings can be readily applied for program design and assessment. Further, they are useful for identifying textbooks, instructional resources or gaps in such resources. While preconceptions by students and instructors exist in any field, this data could provide foundational elements from which to reconstruct those opinions. Our findings are also useful for human resource management (HRM) systems. HRM is a corporate function that is increasingly using competency systems as a basis for selection, training and development (Lucia \& Lepsinger, 1999). The competencies we identified, along with organization-specific needs, can form a useful basis for evaluating candidates and also identifying what the training and development needs of current employees.

\section{References}

Bureau of Labor Statistics, U.S. Department of Labor (2021). Occupational Outlook Handbook, Data for Occupations Not Covered in Detail. https://www.bls.gov/ooh/about/data-for-occupations-notcovered-in-detail.htm

National Center for O*NET Development (2021a). 15-2051.00 - Data Scientists. O*NET OnLine. https://www.onetonline.org/link/custom/15-2051.00

Burrus, J., Jackson, T., Xi, N., \& Steinberg, J. (2013). Identifying the most important 21st century workforce competencies: An analysis of the Occupational Information Network (O*NET). ETS Research Report Series, 2013(2), i-55. https://doi.org/10.1002/j.2333-8504.2013.tb02328.x

Chen, H., Chiang, R. H., \& Storey, V. C. (2012). Business intelligence and analytics: From big data to big impact. MIS quarterly, 36(4), 1165-1188. https://doi.org/10.2307/41703503

Cifuentes, M., Boyer, J., Lombardi, D.A., \& Punnett, L. (2010). Use of O*NET as a job exposure matrix: A literature review. American Journal of Industrial Medicine, 53, 898-914. https://doi.org/10.1002/ajim.20846

Clayton, P. R., \& Clopton, J. (2019). Business curriculum redesign: Integrating data analytics. Journal of Education for Business, 94(1), 57-63. https://doi.org/10.1080/08832323.2018.1502142 


\section{Issues in Information Systems}

Volume 22, Issue 4, pp. 157-167, 2021

De Mauro, A., Greco, M., Grimaldi, M., \& Ritala, P. (2018). Human resources for Big Data professions: A systematic classification of job roles and required skill sets. Information Processing \& Management, 54(5), 807-817. https://doi.org/10.1016/j.ipm.2017.05.004

Debortoli, S., Müller, O., \& vom Brocke, J. (2014). Comparing business intelligence and big data skills. Business \& Information Systems Engineering, 6(5), 289-300. https://doi.org/10.1007/s12599-014-0344-2

Dubey, R., \& Gunasekaran, A. (2015). Education and training for successful career in big data and business analytics. Industrial and Commercial Training, 47(4), 174-181. https://doi.org/10.1108/ICT-08$\underline{2014-0059}$

Hadden, W.C., Kravets, N., \& Carles, M. (2004). Descriptive dimensions of US occupations with data from O*NET. Social Science Research, 33(1), 64-78. https://doi.org/10.1016/S0049-089X(03)00039-5

Irani, Z., \& Love, P. E. (2001). Information systems evaluation: past, present and future. European Journal of Information Systems, 10(4), 183-188. https://doi.org/10.1057/palgrave.ejis.3000408

Lucia, A. D., \& Lepsinger, R. (1999). The art and science of competency models. San Francisco, CA: Jossey-Bass.

Mikalef, P., Giannakos, M. N., Pappas, I. O., \& Krogstie, J. (2018, April). The human side of big data: Understanding the skills of the data scientist in education and industry. In 2018 IEEE Global Engineering Education Conference (EDUCON) (pp. 503-512). https://doi.org/10.1080/10580530.2021.1894515

National Center for O*NET Development (2021a). 15-2051.00 - Data Scientists. O*NET OnLine. https://www.onetonline.org/link/custom/15-2051.00

National Center for O*NET Development (2021b). 15-2051.01 - Business Intelligence Analysts. $O * N E T$ OnLine. https://www.onetonline.org/link/custom/15-2051.01

National Center for O*NET Development (2021c). O*NET OnLine Help: Scales, Ratings, and Standardized Scores. $O^{*} N E T$ OnLine. https://www.onetonline.org/help/online/scales

National Center for O*NET Development (2021d). Knowledge. Skills. Abilities. Work Styles. $O * N E T$ OnLine. https://www.onetonline.org/find/descriptor/browse/Knowledge/

Ozturk, P., \& Hartzel, K. S. (2020). Business Analytics: Addressing the Real Skill Requirements of Employers. In Proceedings of the EDSIG Conference (Vol. 2473, p. 4901). http://proc.iscap.info/2020/pdf/5343.pdf

Persaud, A. (2020). Key competencies for big data analytics professions: a multimethod study. Information Technology \& People, 34(1), 178-203. https://doi.org/10.1108/ITP-06-2019-0290

Peterson, N. G., Mumford, M. D., Borman, W. C., Jeanneret, P. R., Fleishman, E. A., Levin, K. Y., \& Dye, D. M. (2001). Understanding work using the Occupational Information Network (O*NET): 


\section{Issues in Information Systems}

Volume 22, Issue 4, pp. 157-167, 2021

Implications for practice and research. Personnel Psychology, 54(2), 451-492. https://doi.org/10.1111/j.1744-6570.2001.tb00100.x

Sato, A., \& Huang, R. (2015, December). From data to knowledge: A cognitive approach to retail business intelligence. In 2015 IEEE International Conference on Data Science and Data Intensive Systems (pp. 210-217). https://doi.org/10.1109/DSDIS.2015.106

White, Sarah K. What is a business intelligence analyst? A role for driving business value with data. https://www.cio.com/article/3387619/what-is-a-business-intelligence-analyst-a-role-for-drivingbusiness-value-with-data.html 